\title{
Chromosomal polymorphism, climatic factors, and variation in population size of Drosophila willistoni in southern Brazil
}

\author{
V. L. S. Valente and A. M. Araújo
}

Departamento de Genética, Universidade Federal do Rio Grande do Sul, Cx. Postal 1953, 90.001-Porto Alegre, RS, Brazil.

Natural populations of Drosophila willistoni collected every three months over banana baits between September, 1978 and May, 1982 at Parque de Itapuã and Parque do Turvo, Rio Grande do Sul, Brazil, localised in different regions in terms of climate, flora and fauna, were studied with respect to the variation of their chromosomal polymorphism associated with meteorological variables and population fluctuations.

Multiple regression applied to the variation in the population size (dependent variable), macroclimatic data and heterozygous frequency for inversions of chromosomes IIL and III showed that in both places those parameters play very distinct roles regarding $D$. willistoni populations. At Parque do Turvo, where the climate is more constant, the minimum temperature of the month that preceded each month of collection explains 90 per cent of the population variation of the species, whereas at Itapuã, a region presenting greater meteorological instability, intrinsic factors, such as the inversion frequencies together with two climatic variables can account for the same proportion of the variation in population size. Significant correlations were also found between inversions and climate in both places, as well as associations among inversions of the same and different chromosomes.

\section{INTRODUCTION}

Drosophila willistoni is an ecologically versatile species, dominant in most Neotropical forests, although it had also been found in Mexican forests, in sympatry with species from temperate regions (Ehrman and Powell, 1982). Its geographic distribution ranges from central Mexico and Florida to northern Argentina. It was also found by A. R. Cordeiro (unpublished results) at the southernmost locality of Montes Tordillos, $300 \mathrm{~km}$ from Buenos Aires (Winge, 1971).
The flexible and adaptive nature of its chromosomal polymorphism has been shown by $\mathrm{Da}$ Cunha et al. (1950, 1959), Da Cunha and Dobzhansky (1954), Battaglia and Birch (1956), Birch and Battaglia (1957), Da Cunha (1956a, b; 1957), Ayala et al. (1971), Valente et al. (1981), Valente and Araújo (1985), who found shifts in the inversion frequencies associated with environmental variation or ecological factors. However, there are few works on the association of this marker with climatic variability in well defined seasonal regions, such as the State of Rio Grande do Sul, Brazil, situated near the southern limit of the species distribution.

Our objective was to add new information on the chromosomal polymorphism variability of $D$. willistoni populations and try to establish relationships between the cytological data and demographic and environmental parameters, especially the effects of climatic oscillations.

\section{MATERIAL AND METHODS}

Studies were made in two forest parks separated by about $500 \mathrm{~km}$, and in different climatic regions: Parque de Itapuã $\left(30^{\circ} 17^{\prime} \mathrm{S}, 51^{\circ} 1^{\prime} \mathrm{W}\right)$ and Parque Florestal Estadual do Turvo $\left(27^{\circ}, 21^{\prime} \mathrm{S}, 53^{\circ}\right.$ and $54^{\circ} 10^{\prime} \mathrm{W}$ ). More details about both places are found in Valente and Morales (1985). Parque do Turvo is situated in a "hot winter" region, and Parque de Itapuã is localised in a "cold winter" area (Plano Integrado para o Desenvolvimento do Litoral Norte do Rio Grande do Sul, 1976). 
The natural populations of Drosophila willistoni were collected over conventional banana baits during an average of 5 days (the time spent at each site was about 30 minutes) every three months between September, 1978 and May, 1982. The baits measured about $50 \mathrm{~cm}$ in diameter and were made from a total of $3 \mathrm{~kg}$ of bananas. Nearly half of the samples can be considered synchronic, since they had only an interval of a week between places.

The egg samples from females captured in nature and placed individually into tubes with culture medium were processed using Ashburner's technique (1967), during the late third larval stage.

Macroclimatic data such as temperature $\left({ }^{\circ} \mathrm{C}\right)$, humidity, rainfall and insolation corresponding to the collecting month were obtained from meteorological stations nearer the places of study: Iraí Station (about $60 \mathrm{~km}$ from Parque do Turvo$\left.27^{\circ} 11^{\prime} \mathrm{S}, 53^{\circ} 14^{\prime} \mathrm{W}\right)$ and Porto Alegre Station (about $60 \mathrm{~km}$ from Itapuã-30 $01^{\prime} \mathrm{S}, 53^{\circ} 13^{\prime} \mathrm{W}$ ). (Appendix 1).

The Pearson Correlation and Multiple Regression subprograms belonging to the Statistical Package for the Social Sciences (Nie et al., 1975) were utilised in order to obtain correlations between heterozygous frequencies for inversions of Drosophila willistoni and the climatic parameters considered, as well as to evaluate their effect over population size oscillations, estimated by the indirect method (No. of $D$. willistoni/total No. of flies per sample).

The tests were carried out with the data transformed as follows: population size, temperature, rainfall and insolation in common logarithms, humidity and inversion frequencies of chromosomes IIL and III by angular transformation.

\section{RESULTS}

The analysis of the associations among climate, population size and inversion frequencies is related only to chromosomes IIL and III, which are the most polymorphic in our samples among the five chromosome arms of the larval salivary glands (Dobzhansky, 1950). The chromosome arms XL, $X R$ and IIR are practically homozygous in our samples.

Table 1 shows the frequencies for the heterozygotes of the most common inversions (minimum value of 10 per cent, at least for one of the samples). As can be seen in the columns regarding total heterozygosity, the values are very high in most samples for both chromosomes. When the frequencies of each inversion are observed one by one, great oscillations are found. Furthermore, it is also noticeable that, in the 19 samples studied, the frequencies of the overlapping inversions IIL D and IIL E exceed 50 per cent in 17 of them, exhibiting extreme values, ranging from 42 to 80 per cent, being, therefore, in most cases heterotic. In chromosome III this tendency also appears, although sporadically, for inversion B.

Table 2 presents the relative frequencies of $D$. willistoni in the samples and its variations during the whole collecting period. It is the dominant species at Parque do Turvo, where its total frequency is 46 per cent and the second most abundant species at Parque de Itapuã (11 per cent), where the introduced species $D$. simulans is the dominant one (77 per cent of total frequencies) (Valente and Araújo, submitted).

Fig. 1 represents the variation in the frequency of Drosophila willistoni (from table 2B) in parallel with total heterozygosity for chromosomes IIL and III, and the heterozygous frequencies for inversions of the same chromosomes at Parque de Itapuã and Parque do Turvo (from table 1).

It can be seen that the total heterozygosity of chromosome III for Itapuã and IIL for Turvo oscillates more or less in parallel with the population size of the species.

In relation to the frequencies of each inversion it was verified that in Itapuã IIL D, E and F present an oscillation apparently the inverse of that of the population in the first samples, tending to be synchronic with it in the succeeding ones. $\mathrm{III}_{\mathrm{J}}$ and $\mathrm{III}_{\mathrm{B}}$, particularly the latter, exhibit larger frequencies when the population is in expansion.

Among the samples from Itapuã there is also a strong agreement in the frequencies of IIL D and E (excepting those of January and April, 1981) and an inverse tendency in those of inversions IIL $A$ and $B$ and $I_{B} I_{B}$ and $I I I_{C}$.

The inversion frequencies of IIL D and $E$ at Parque do Turvo, as well as those of $\mathrm{II}_{\mathrm{L}} \mathrm{H}$ and $\mathrm{III}_{\mathrm{J}}$ seem to follow the largest relative frequencies of D. willistoni, whereas in those of $\mathrm{III}_{\mathrm{C}}$, it does not occur in all samples. Strong linkage was also observed here between IILD and E inversions, with practically identical frequencies.

An analysis of the role of the inversions and climatic factors on population size was made through the multiple regression technique. The results for Parque de Itapuã and Parque do Turvo are shown in tables 3 and 4 , respectively. There are remarkable differences for both localities when the contribution of each variable is compared. By examining the multiple coefficient of determination $\left(r^{2}\right)$ in table 3 it is possible to see that five 


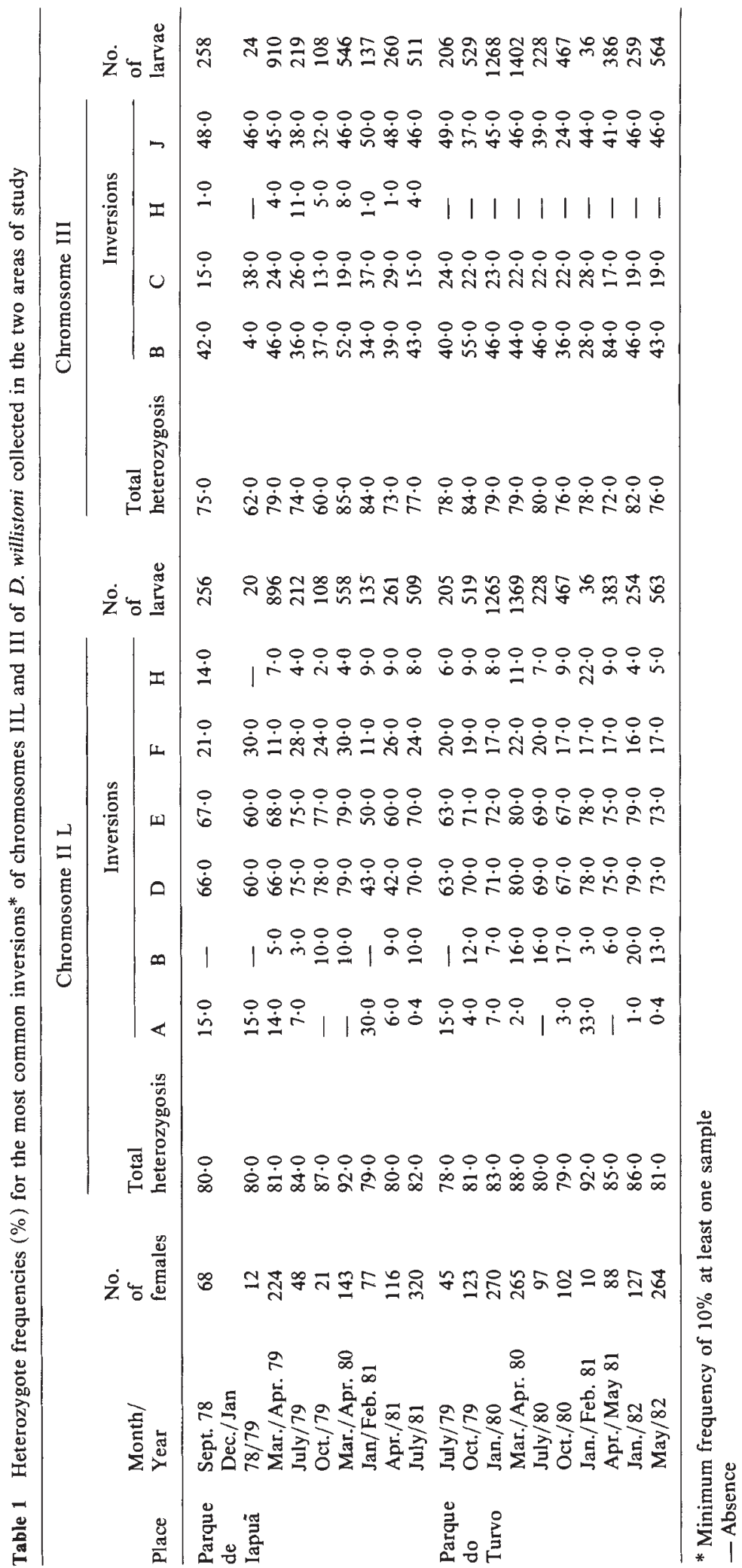




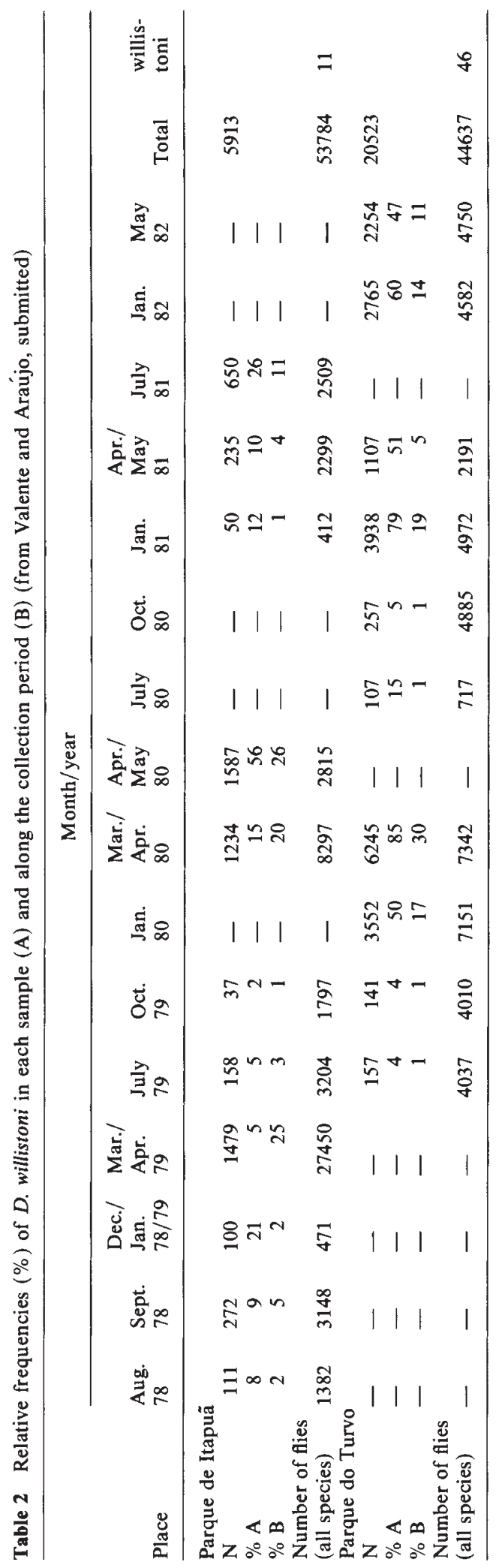




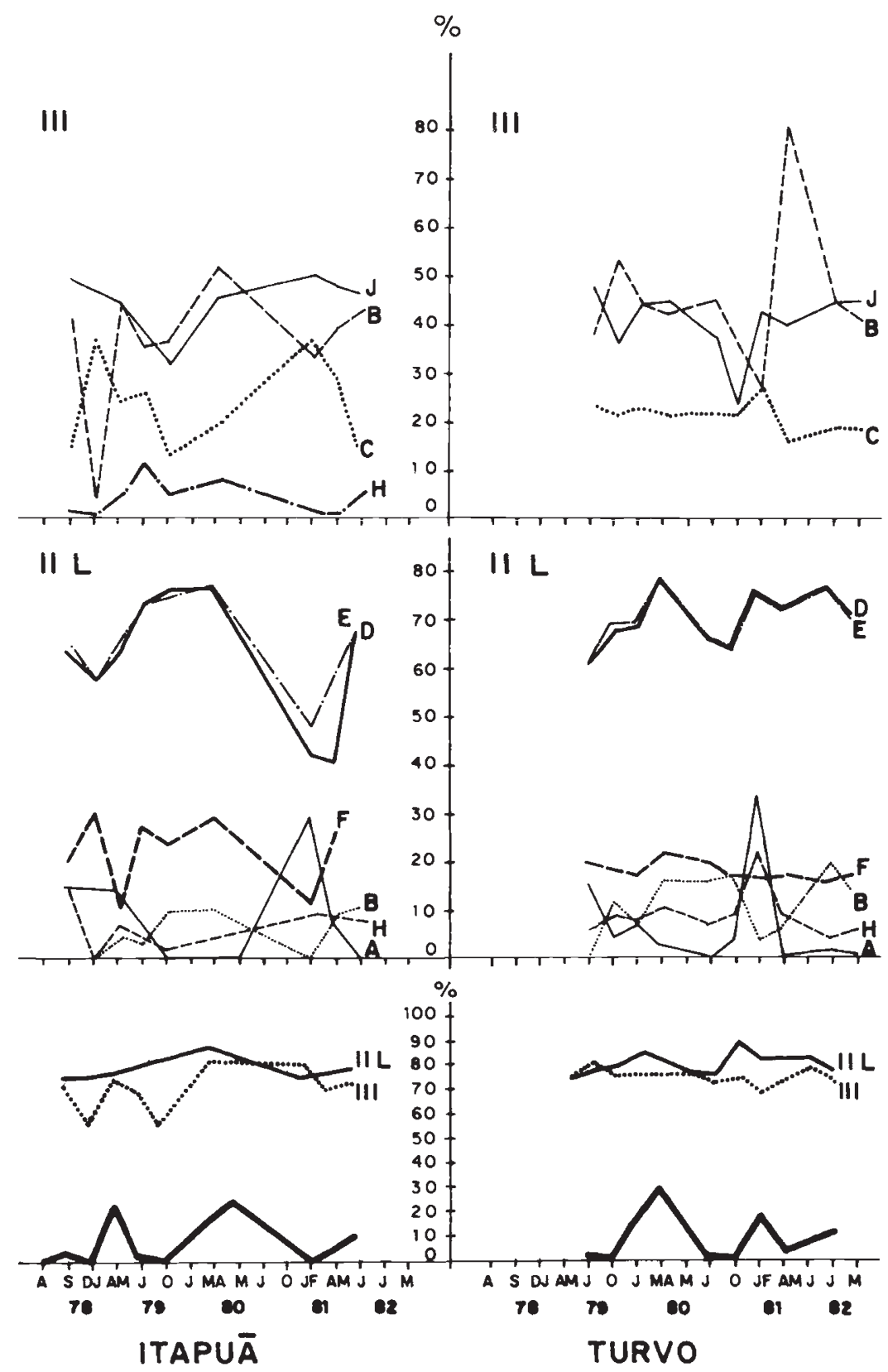

Figure 1 Variation in population size of $D$. willistoni at Itapuã and Turvo (thick line, below) and total frequency of heterozygotes inversions in chromosomes $\mathrm{II}_{\mathrm{L}}$ and III. Upper graphs: variation in the frequency of specific inversions in chromosomes $\mathrm{II}_{\mathrm{L}}$ and III.

variables (inversion $\mathrm{B}$ of the third chromosome, humidity at the collection month, inversions IIL $\mathrm{E}$, III $\mathrm{J}$ and insolation at the collection month) can account for 90 per cent $\cdot 0$ the variation in size. This same quantitative effect is achieved at Parque do Turvo by a single variable, namely, minimum temperature in the month before collection (table
4). The contribution of inversions IIL E, IIL B, IIL $\mathrm{F}$, and IIL $\mathrm{H}$ is negligible there.

Table 5 shows the correlation matrix among 19 selected variables of the present study. Values for Parque de Itapuã are placed above and those for Turvo below the diagonal. There are three types of significant associations that deserve attention 
Table 3 Results of the stepwise multiple regression among population size (dependent variable), climatic variables and inversions (independent variables) at Parque de Itapuã $\left(\mathbf{B}=\right.$ partial regression coefficient; $\beta=$ standardized regression coefficient; $r^{2}=$ coefficient of determination; $\mathrm{F}=$ variance ratio)

\begin{tabular}{|c|c|c|c|c|}
\hline Variable & B & $\beta$ & $r^{2}$ & $\mathrm{~F}$ \\
\hline Inversion B (chromosome III) & $11 \cdot 04656$ & $1 \cdot 45937$ & $0 \cdot 25618$ & $91346 \cdot 889 \ddagger$ \\
\hline Humidity at the collection month & -86.98744 & $-2 \cdot 75940$ & 0.43503 & $125830 \cdot 972 \ddagger$ \\
\hline Inversion $\mathrm{J}$ (chromosome III) & $7 \cdot 39525$ & $0 \cdot 32712$ & 0.81765 & $9438 \cdot 275 \ddagger$ \\
\hline Insolation at the collection month & $-10 \cdot 74973$ & -1.92376 & 0.90443 & $98898 \cdot 072 \ddagger$ \\
\hline Inversion $\mathrm{H}$ (chromosome III) & $-10 \cdot 27072$ & -0.82853 & 0.99359 & $44548 \cdot 992 \ddagger$ \\
\hline
\end{tabular}

$\ddagger=P<0.001$

Table 4 Results of the stepwise multiple regression among population size (dependent variable), climatic variables and inversions (independent variables) at Parque do Turvo. $\left(\mathrm{B}=\right.$ partial regression coefficient; $\beta=$ standardized regression coefficient; $r^{2}=$ coefficient of determination; $\mathrm{F}=$ variance ratio)

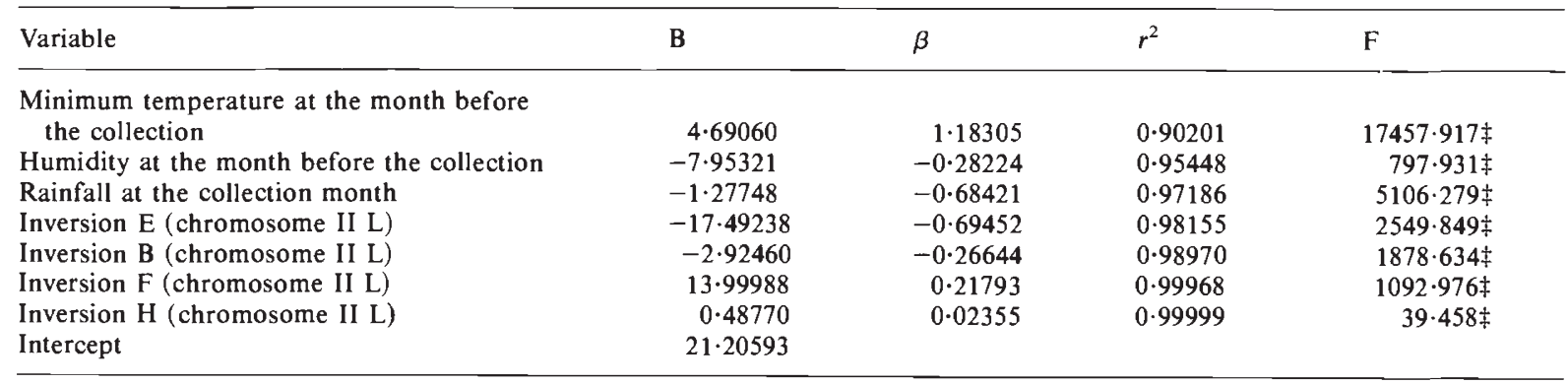

$\ddagger=P<0.001$

here: those between chromosome inversions and climatic variables, those between inversions in the same chromosome and those between different ones.

At Itapuã the two climatic variables that correlate with inversion (humidity at the collection month $=$ UmiCol, and insolation at the collection month $=$ InsCol) are both highly negatively correlated $\left(r=-0.94^{* *}\right)$, as would be expected; each inversion correlates significantly with InsCol and UmiCol by a similar correlation coefficient, although with a reverse sign (the exception being inversion III B).

At Turvo, inversions of the third chromosome are not correlated with climatic variables with only one exception: inversion $\mathrm{J}$ with InsAnt (insolation in the month before the collection; $r=0 \cdot 81^{* *}$ ). Inversion IIL D and $\mathrm{E}$ are correlated, of course, with the same climatic variables (TAntMed, TColMed, InsAnt and PCol); it is interesting to note, however, their very different behaviour at Parque de Itapuã (above diagonal). II $\mathrm{L}_{\mathrm{F}}$ is another inversion significantly correlated with climatic variables (UmiCol and UmiAnt).
When correlation among inversions in the same chromosome are examined, four significant values are found for Itapuã involving only the 2nd chromosome $\left(r_{\mathrm{D}, \mathrm{E}}=0.94^{* *} ; r_{\mathrm{A}, \mathrm{D}}=-0.67^{*} ; r_{\mathrm{A}, \mathrm{E}}=\right.$ $-0 \cdot 80^{*}$ and $\left.r_{\mathrm{A}, \mathrm{B}}=-0 \cdot 85^{* *}\right)$. At Parque do Turvo inversion $\mathrm{A}, \mathrm{D}$ and $\mathrm{E}$ from the 2 nd chromosome are related $\left(r_{\mathrm{D}, \mathrm{E}}=0.99^{*} ; r_{\mathrm{A}, \mathrm{B}}=-0.65^{*}\right.$ and $r_{\mathrm{A}, \mathrm{H}}=$ $0.63^{*}$ ), while only inversions $\mathrm{B}$ and $\mathrm{C}$ from the third chromosome are associated $\left(r_{\mathrm{B}, \mathrm{C}}=-0 \cdot 82^{* *}\right)$. As for association of inversions belonging to different chromosomes, at Itapuã both $\mathrm{II}_{\mathrm{L}} \mathrm{D}, \mathrm{E}$ correlates with II C, $\mathrm{H}, \mathrm{J}$ together with $\mathrm{II}_{\mathrm{L}} \mathrm{A}$, III C and $\mathrm{II}_{L} \mathrm{H}$, III $\mathrm{B}$; for Parque do Turvo these are $\mathrm{II}_{\mathrm{L}}$ A with II B,C and $\mathrm{II}_{\mathrm{L}} \mathrm{H}$, II C.

Tables 6 and 7 show the estimated mean number of inversions per chromosome arm and per female in the samples from Itapuã and Turvo, respectively. The left arm of chromosome II and chromosome III are the most polymorphic in the two localities. Considering the total mean per female there are no differences between Itapuã and Turvo, although the latter showed a smaller standard deviation, suggesting a more stable distribution. 


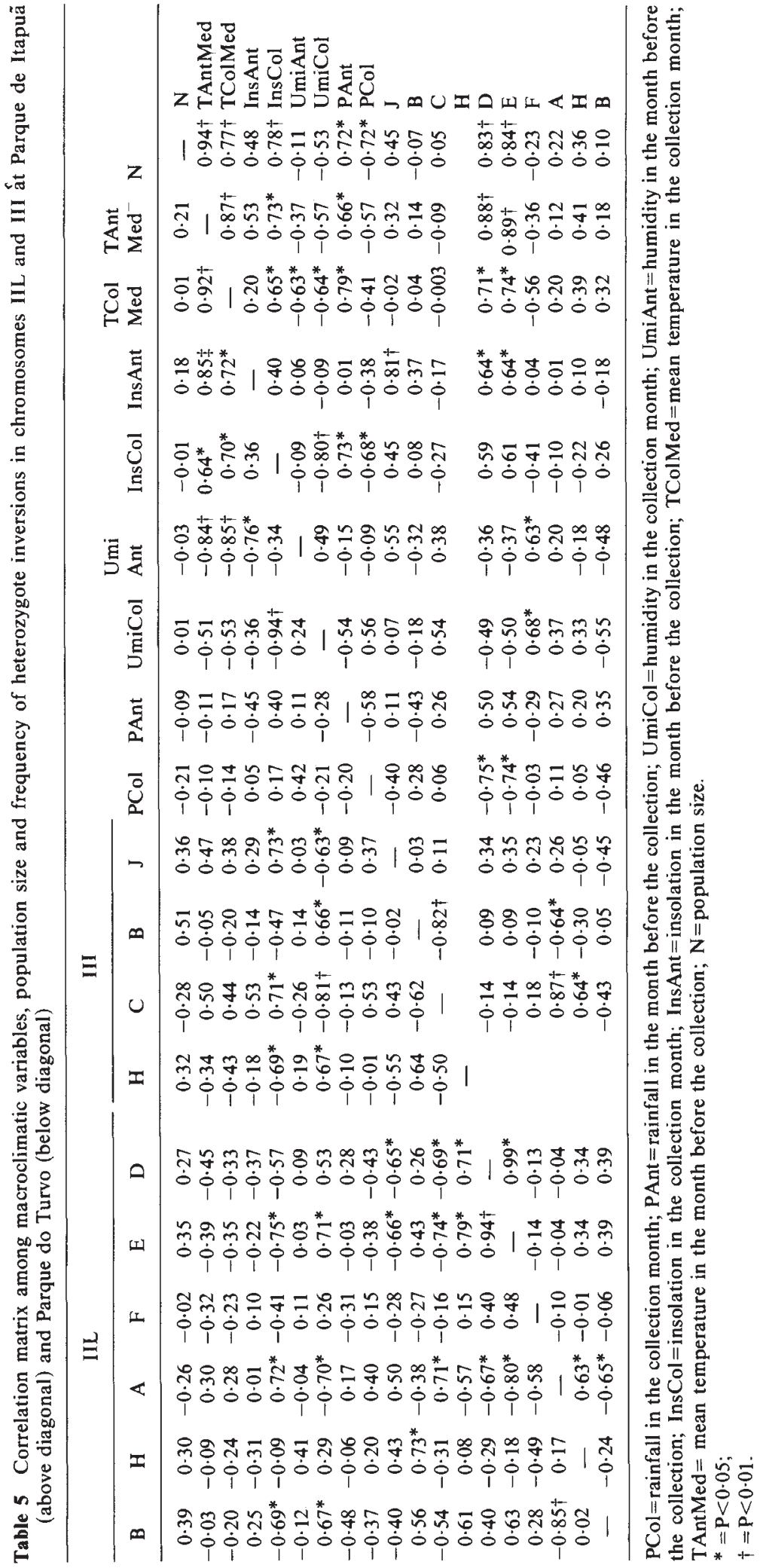


Table 6 Mean number of inversions per chromosome and per female of Drosophila willistoni from Parque de Itapuã

\begin{tabular}{|c|c|c|c|c|c|c|c|c|}
\hline \multirow{2}{*}{$\begin{array}{l}\text { Samples } \\
\text { Month/Year }\end{array}$} & \multirow[b]{2}{*}{ Season } & & \multicolumn{5}{|c|}{ Chromosome } & \multirow{2}{*}{$\begin{array}{l}\text { Mean no. } \\
\text { Invs/ } 9\end{array}$} \\
\hline & & & XL & XR & II L & II R & III & \\
\hline Sept./78 & & $\mathbf{N}$ & 258 & 258 & 256 & 259 & 258 & \\
\hline \multirow{2}{*}{ Jan./79 } & Summer & & $0 \cdot 00$ & $0 \cdot 14$ & $1 \cdot 70$ & 0.09 & 0.88 & $2 \cdot 73$ \\
\hline & & $\mathbf{N}$ & 23 & 21 & 20 & 23 & 24 & \\
\hline \multirow[t]{2}{*}{ July/79 } & Winter & & 0.01 & 0.02 & 1.95 & 0.05 & $1 \cdot 25$ & 3.22 \\
\hline & & $\mathbf{N}$ & 221 & 220 & 212 & 221 & 219 & \\
\hline \multirow{2}{*}{ Oct./79 } & Spring & & 0.00 & 0.00 & 1.91 & 0.05 & $0 \cdot 80$ & $2 \cdot 78$ \\
\hline & & $\mathbf{N}$ & 107 & 107 & 108 & 107 & 108 & \\
\hline \multirow[t]{2}{*}{ Mar./80 } & Autumn & & 0.00 & 0.00 & $2 \cdot 02$ & 0.04 & $1 \cdot 25$ & $3 \cdot 34$ \\
\hline & & $\mathbf{N}$ & 547 & 547 & 558 & 549 & 546 & \\
\hline \multirow[t]{2}{*}{ July/81 } & Winter & & 0.00 & 0.00 & 1.83 & 0.02 & 1.08 & $2 \cdot 92$ \\
\hline & & & 511 & 511 & 509 & 511 & 511 & \\
\hline Total & & & 0.006 & 0.02 & 1.93 & 0.05 & $1 \cdot 24$ & $3 \cdot 24 \pm 0.63$ \\
\hline
\end{tabular}

Table 7 Mean number of inversions per chromosome and per female of Drosophila willistoni from Parque do Turvo

\begin{tabular}{|c|c|c|c|c|c|c|c|c|}
\hline \multirow{2}{*}{$\begin{array}{l}\text { Samples } \\
\text { Month/Year }\end{array}$} & \multirow{2}{*}{$\begin{array}{l}\text { Season } \\
\text { Season }\end{array}$} & & \multicolumn{5}{|c|}{ Chromosome } & \multirow{2}{*}{$\begin{array}{l}\text {-Mean no. } \\
\text { Inv/ } 9\end{array}$} \\
\hline & & & XL & XR & II L & II R & III & \\
\hline \multirow[t]{2}{*}{ July/79 } & Winter & & 0.004 & 0.01 & $1 \cdot 72$ & 0.05 & $1 \cdot 17$ & $2 \cdot 96$ \\
\hline & & $\mathbf{N}$ & 205 & 205 & 205 & 205 & 206 & \\
\hline \multirow[t]{2}{*}{ Oct./79 } & Spring & & 0.02 & 0.02 & $1 \cdot 85$ & 0.09 & $1 \cdot 20$ & $3 \cdot 19$ \\
\hline & & $\mathbf{N}$ & 516 & 516 & 519 & 527 & 529 & \\
\hline \multirow[t]{2}{*}{ Jan. $/ 80$} & Summer & & 0.01 & 0.004 & $1 \cdot 19$ & 0.04 & $1 \cdot 24$ & $2 \cdot 46$ \\
\hline & & $\mathbf{N}$ & 1289 & 1289 & 1265 & 1289 & 1268 & \\
\hline \multirow[t]{2}{*}{ Apr./ 80} & Autumn & & 0.00 & 0.00 & $2 \cdot 11$ & 0.04 & $1 \cdot 22$ & $3 \cdot 33$ \\
\hline & & $\mathbf{N}$ & 1407 & 1406 & 1369 & 1413 & 1402 & \\
\hline \multirow[t]{2}{*}{ July/ 80} & Winter & & $0 \cdot 00$ & $0 \cdot 00$ & $1 \cdot 82$ & 0.06 & $1 \cdot 11$ & $2 \cdot 98$ \\
\hline & & $\mathbf{N}$ & 228 & 228 & 228 & 228 & 228 & \\
\hline \multirow[t]{2}{*}{ Oct. $/ 80$} & Spring & & 0.00 & 0.03 & $1 \cdot 79$ & 0.04 & 1.08 & $2 \cdot 93$ \\
\hline & & $\mathbf{N}$ & 470 & 470 & 467 & 471 & 467 & \\
\hline \multirow[t]{2}{*}{ Feb./81 } & Summer & & 0.00 & 0.00 & $2 \cdot 31$ & $0 \cdot 14$ & 1.00 & $3 \cdot 44$ \\
\hline & & $\mathbf{N}$ & 36 & 36 & 36 & 36 & 36 & \\
\hline \multirow[t]{2}{*}{ Apr./81 } & Autumn & & 0.00 & $0 \cdot 00$ & $1 \cdot 82$ & 0.03 & $1 \cdot 42$ & $3 \cdot 37$ \\
\hline & & $\mathbf{N}$ & 355 & 355 & 383 & 384 & 386 & \\
\hline \multirow[t]{2}{*}{ Jan./82 } & Summer & & 0.00 & 0.00 & 1.98 & 0.04 & $1 \cdot 15$ & $3 \cdot 18$ \\
\hline & & $\mathrm{N}$ & 257 & 257 & 254 & 251 & 259 & \\
\hline \multirow[t]{2}{*}{ May/82 } & Autumn & & 0.004 & 0.00 & 1.83 & 0.05 & $1 \cdot 13$ & $3 \cdot 00$ \\
\hline & & $\mathbf{N}$ & 566 & 566 & 563 & 568 & 564 & \\
\hline Total & & & 0.004 & 0.006 & $1 \cdot 84$ & 0.06 & $1 \cdot 17$ & $3.08 \pm 0.08$ \\
\hline
\end{tabular}

\section{DISCUSSION}

The simultaneous occurrence of such a large number of inversions in populations of Drosophila willistoni in Rio Grande do Sul, geographically near the southern border of the species distribution, raises the following question: how does this high degree of polymorphism contribute to the adapta- tion of the populations to the environmental variations? In this State, due to its climatic characteristics, the effects of the meteorological conditions over flora, fauna and genetics of populations are probably more effective than in typically tropical Brazilian regions.

Although the frequencies of inversions are similar in both places, the correlation matrix (table 
5) shows clearly that they play different roles. As far as populations size is concerned, the differences found in multiple regression for Itapuã and Turvo show how much biotic and abiotic variables may act differently in both places.

Thus, the populations from Parque do Turvo seem to depend much more on the macroclimatic conditions, especially on the previous minimum temperature, than on any other of the variables considered. On the contrary, at Itapuã, the chromosomal constitution of the species (especially in regard to the inversions of chromosome III) seems to be the most effective factor with humidity playing a minor role.

Such results were surprising at first sight, since Itapuã was considered a marginal environment when compared to Turvo as far as lepidoptera populations are concerned (Pansera and Araújo, 1983). It would be expected then, that biotic factors should be more relevant at Turvo than at Itapuã; this was not the case. In view of the circumstances we conjecture that at Turvo the climatic factors that regulate the cycle of plants on which the populations of $D$. willistoni depend are preponderant, whereas at Itapuã the unpredictability of the environment makes chromosome polymorphism a useful way to overcome that difficulty.

Unfortunately, we have not found in the literature similar data in order to compare them with our data. However, it is also important to point out that the coexistence and competition with other sympatric species (whose frequencies did not take part in the regression) must certainly play an important role in the regulation of Drosophila willistoni populations. Pavan et al. (1957) have already suggested that when $D$. willistoni, $D$. tropicalis and $D$. paulistorum are sympatric, the dominant one shows heterotic inversions. In our samples, however, sibling species of $D$. willistoni were not detected (in function of their own geographic distribution). A similar relationship of dominance between $D$. willistoni and $D$. simulans has been observed in the present study, although without any evident change in the frequencies of the heterotic inversions $\mathrm{II}_{\mathrm{L}} \mathrm{D}, \mathrm{E}$.

Heterotic inversions in Drosophila willistoni were recorded previously by many authors such as Da Cunha (1953), Da Cunha et al. (1959), Dobzhansky and Pavlovsky (1958) and Cordeiro et al. (1960), which seems to be advantageous for the species in some extension, despite of increasing the homozygous mortality.

Among the correlations involving inversions of the same chromosome arm we believe are the most important those between $\mathrm{II}_{\mathrm{L}} \mathrm{A}$ and $\mathrm{E}(r=-0.80$; $P<0.05)$ from Itapuã and $\mathrm{II}_{\mathrm{L}} \mathrm{A}$ and $\mathrm{H}(r=0.63$;
$P<0.05$ ) from Turvo, since they are sufficiently distant to allow free recombination. As this is not occurring their association probably is advantageous for individuals possessing them. The same explanation can be offered to those inversions belonging to the different chromosomes, as $\mathrm{II}_{\mathrm{L}} \mathrm{D}, \mathrm{E}$ and $\mathrm{III} \mathrm{C}, \mathrm{H}, \mathrm{J} ; \mathrm{II}_{\mathrm{L}} \mathrm{A}$ and $\mathrm{III} \mathrm{C}, \mathrm{II}_{\mathrm{L}} \mathrm{H}$ and III B for Itapuã, and $\mathrm{II}_{\mathrm{L}} \mathrm{A}$ with III B,C, and IIL $\mathrm{H}$ with III C for Turvo (table 5).

Interchromosomal associations have been found in several species of Drosophila as for instance, Da Cunha et al. (1950) for D. willistoni, Levitan and Salzano (1959) for D. guaramunu (see also the review by Levitan (1958), Brncic (1961) for D. pavani, Sene (1981) for D. mercatorum. Any attempt of interpretation of such relationships should involve experimental work as well as a deeper knowledge of the physiological role played by inversions.

Finally, the constant mean number of inversions per female (about 3 ) over the years and in both places leads us to suggest that probably it reflects the action of stabilising selection, thus supporting Carson's hypothesis of homoselection at the limit of the species distribution. Similar values were reported by Da Cunha et al. (1950), Da Cunha and Dobzhansky (1954), Cordeiro (1961), Cordeiro et al. (1960) in samples from Rio Grande do Sul.

Findings from smaller latitudes where the mean number of inversions per female is around 9 ( Da Cunha et al., 1950) suggest that such populations are close to the centre of origin of Drosophila willistoni.

Acknowledgements Thanks are due to directors of Parque do Turvo and Parque de Itapuã for allowing us to work in those places. We also express our gratitude to $8^{\circ}$ Distrito de Meteorologia of Ministério da Agricultura, Centro de Processamento de Dados of Universidade Federal do Rio Grande do Sul and to Conselho Nacional de Desenvolvimento Científico e Tencológico (CNPq), V Câmara (UFRGS), Fundação de Amparo à Pesquisa do Estado do Rio Grande do Sul (FAPERGS) and PNUDUNESCO (RLA 78024) for the financial support.

\section{REFERENCES}

ASHBURNER, M. 1967. Patterns of puffing activity in the salivary gland chromosomes of Drosophila. I. Autosomal puffing patterns in a laboratory stock of Drosophila melanogaster. Chromosoma, 27, 47-63.

AYALA, F. J., POWELL, J. R. AND DOBZHANSKY, T. 1971. Polymorphism in continental and island populations of Drosophila willistoni. Proc. natl. Acad. Sci. USA, 68, 24802483. 
BAtTAglia, B. AND BIRCH, L. C. 1956. Polimorfismo cromossomico e fattori ecologici della selezione in Drosophila willistoni. Archivio Zoologico Italiano, 41, 281315.

BIRCH, L. C. AND BATTAGLIA, B. 1957. Selection in Drosophila willistoni in relation to food. Evolution, 11, 94-105.

BRNCIC, D. 1961. Non-random association of inversions in Drosophila pavani. Genetics, 46, 401-406.

CORDEIRO, A. R., SALZANO, F. M. AND MARQUES, V. B. 1960. An interracial hybridization experiment in natural populations of Drosphila willistoni. Heredity, 15, 35-45.

DA CUNHA, A. B. 1953. Chromosomal inversions with sex limited effects. Nature, 172, (4383), 815-816.

DA CUNHA, A. B. 1956a. Adaptation of carriers of different chromosomal types in Drosophila willistoni to a variety of environments. Rev. Bras. Biol., 16, 264-272.

DA CUNHA, A. B. 1956 b. Differential viability favoring inversion heterozygotes in Drosophila willistoni. Evolution, X: 231234.

DA Cunha, A. B. 1957. Contribuicã as estudo de adaptacáo das populacoés de Drosophila (Diptera) a diferentes levedos. Bol. Fac. Fil. Ciên. chetr. Univ. S. Paulo, 220, 7-56.

DA CUNHA, A. B. AND DOBZHANSKY, T. 1954. A further study of chromosomal polymorphism in Drosophila willistoni in its relation to the environment. Evolution, 8, 119-134.

DA CUNHA, A. B., BURLA, H. AND DOBZHANSKY, T. 1950. Adaptive chromosomal polymorphism in Drosophila willistoni. Evolution, 4, 212-235.

DA CUNHA, A. B., DOBZHANSKY, T., PAVLOVSKY, O. AND SPASSKY, B. 1959. Genetics of natural populations. XXVIII. Supplementary data on the chromosomal polymorphism in Drosophila willistoni in its relation to the environment. Evolution, 13, 389-404.

DOBZHANSKY, T. 1950. The chromosomes of Drosophila willistoni. J. Hered., 41, 156-158.

DOBZHANSKY, T. AND PAVLOVSKY, O. 1958. Interracial hybridization and break down of coadapted gene complexes in Drosophila willistoni. Proc. Natl. Acad. Sci. USA, 44, 622-629.

EHRMANN, L. AND POWEll, J. R. 1982. The Drosophila willisitoni species group., In The Genetics and Biology of Drosophila. Ashburner, M, Carson, H. L. and Thompson, J. N. Jr. (eds.). Academic Press, London and New York, Vol. 3b, pp. 193-225.
LEVITAN, M. 1958. Non-random associations of inversions. Cold Spring Harbor Symp. Quant. Biol. 23, 251-268.

LEVITAN, M. AND SALZANO, F. M. 1959. Studies of linkage in populations. III. An association of linked inversions of Drosophila guaramunu. Heredity, 13, 243-248.

NIE, N. H., HULl, C. H., JENKINS, J. G., STEINBRENNER, K. AND BENT, D. H. 1975. Statistical Package for the Social Sciences. 2nd ed. McGraw-Hill Book Company.

PANSERA, M. C. AND ARAúJO, A. M. 1983. Distribution and heritability of the red raylets in Heliconius erato phyllis (Lepid.; Nymph.). Heredity, 51, 643-652.

PAVAN, C, DOBZHANSKY, T., AND DA CUNHA, A. B. 1957. Heterosis and elimination of weak homozygotes in natural populations of three related species of Drosophila. Proc. Natl, Acad. Sci. USA, 43, 226-234.

SENE, F. M. 1981. Análise da variabilidade cromossômica de populacóes naturais de Drosophila mercatorum pararepleta Dobzhansky and Pavan, 1943. Tese de Livre Docência, Universidade de São Paulo.

VALENTE, V. L. S. AND ARAÚJO, A. M. 1985. Observations of natural populations of Drosophila willistoni and its association with the choice of feeding and breeding sites. Rev. Bras. Genet., VIII, 271-284.

VALENTE, V. L. S. AND ARAÚJO, A. M. (submitted). Ecological aspects of Drosophila species inhabiting wild environments in Southern Brazil (Diptera; Drosophilidae). I. Distribution, abundance, food preferences and breeding sites.

VALENTE, V. L. S. AND MORALES, N. B. 1985. New inversions and qualitative description of inversion heterozygotes in natural populations of Drosophila willistoni inhabiting two different regions in the State of Rio Grande do Sul, Brazil. Rev. Bras. Genet, VIII, 1, 167-173.

VALENTE, V. L. S., SAAVEDRA, C. C. R., ARAÚJo, A. M. AND MORALES, N. B. 1981. Observations on the attraction of Drosophila species for different baits and chromosomal polymorphism in Drosophila willistoni. Drosophila Information Service, 56, 147-149.

WINGE, H. 1971. Níveis de divergência evolutiva no grupo criptico da Drosophila willistoni. Tese de Doutoramento. Universidade Federal do Rio Grande do Sul. 


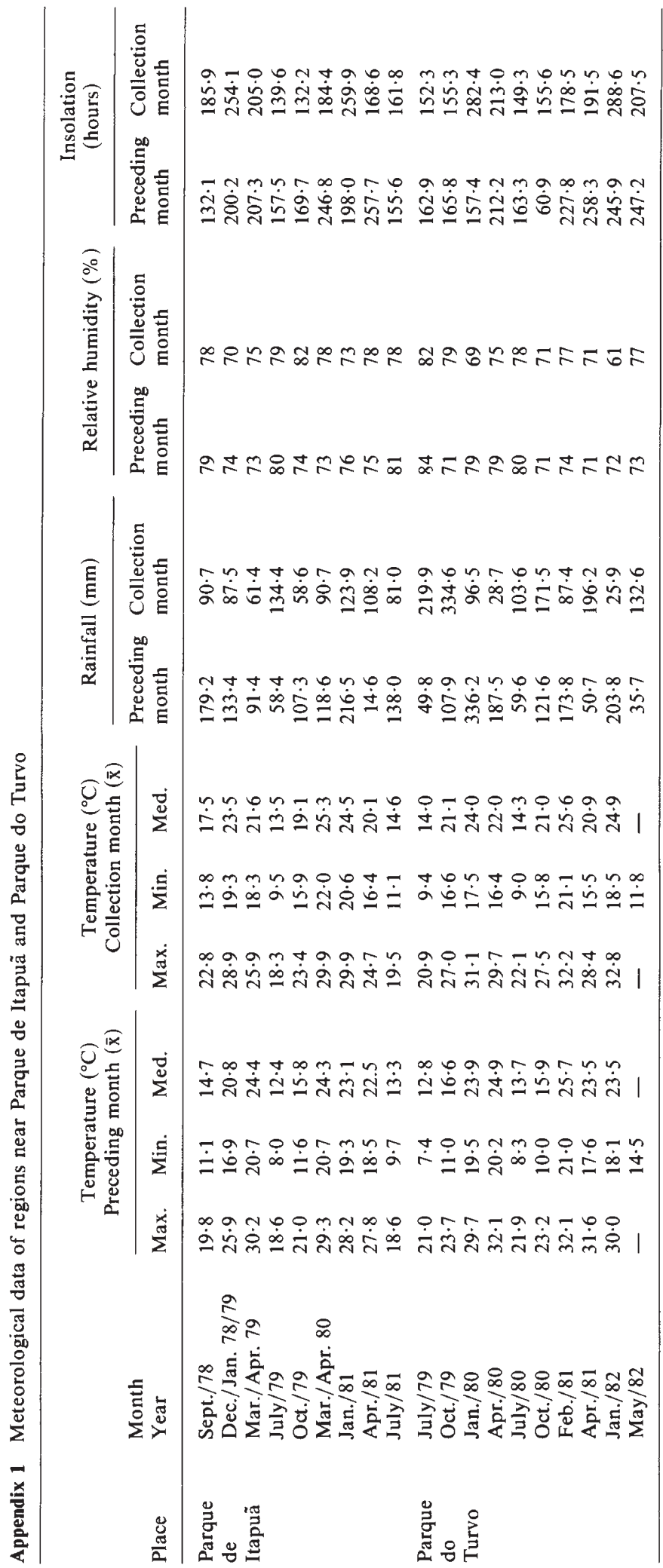

